\title{
Role of $\mathrm{NaCl}, \mathrm{CO}_{2}$, and $\mathrm{H}_{2} \mathrm{~S}$ on Electrochemical Behavior of 304 Austenitic Stainless Steel in Simulated Oil Industry Environment
}

\author{
Hany S. Abdo (1) and Asiful H. Seikh *(]) \\ Mechanical Engineering Department, King Saud University, P.O. Box 800, Al-Riyadh 11421, Saudi Arabia; \\ habdo@ksu.edu.sa \\ * Correspondence: aseikh@ksu.edu.sa
}

check for updates

Citation: Abdo, H.S.; Seikh, A.H. Role of $\mathrm{NaCl}, \mathrm{CO}_{2}$, and $\mathrm{H}_{2} \mathrm{~S}$ on Electrochemical Behavior of 304 Austenitic Stainless Steel in Simulated Oil Industry Environment. Metals 2021, 11, 1347. https://doi.org/ 10.3390/met11091347

Academic Editor: Sónia Simões

Received: 13 July 2021

Accepted: 20 August 2021

Published: 27 August 2021

Publisher's Note: MDPI stays neutral with regard to jurisdictional claims in published maps and institutional affiliations.

Copyright: (c) 2021 by the authors. Licensee MDPI, Basel, Switzerland. This article is an open access article distributed under the terms and conditions of the Creative Commons Attribution (CC BY) license (https:// creativecommons.org/licenses/by/ $4.0 /)$.

\begin{abstract}
The electrochemical behavior of 304 austenitic stainless steel (304ASS) was studied by different methods such as potentiodynamic polarization, EIS, SEM, and Raman spectroscopy. Potentiodynamic polarization data suggest that 304 ASS could be more susceptible to corrosion due to the presence of $\mathrm{H}_{2} \mathrm{~S}$. The coexistence of $\mathrm{H}_{2} \mathrm{~S}$ and $\mathrm{Cl}^{-}$-type ionic species in 304 ASS lead to a decrease in the corrosion resistance as compared to the $\mathrm{H}_{2} \mathrm{~S}$-free condition. It is seen that $\mathrm{CO}_{2}$ helps form a passive layer on the metallic surface, which eventually decreases its corrosion rate. Raman spectroscopy analysis shows that the passive layer developed under different condition consists of $\mathrm{FeCO}_{3}, \mathrm{FeS}_{2}, \mathrm{Fe}_{2} \mathrm{O}_{3}, \mathrm{Fe}(\mathrm{OH})_{2}$, etc. SEM images further confirm that elemental $\mathrm{S}^{-}$and $\mathrm{Cl}^{-}$can infiltrate the passive film and cause the passive film to deteriorate.
\end{abstract}

Keywords: ASS 304; potentiodynamic polarization; EIS; passivity; Raman spectroscopy

\section{Introduction}

During the gas and oil production, $\mathrm{CO}_{2}$ corrosion can cause pipeline failures [1-7], and this problem can become a threat when emission gasses are compressed into deep geological layers (Carbon Capture and Storage (CCS)) during combustion processes [8,9]. Commonly, steels used in industrial pipeline form layers of $\mathrm{FeCO}_{3}$ (siderite) [10-17]. Initially, a corrosive environment has been formed due to the dissolution of $\mathrm{CO}_{2}$. Since the solubility of $\mathrm{FeCO}_{3}$ in water $\left(\mathrm{pK} \mathrm{sp}=10.54\right.$ at $25^{\circ} \mathrm{C}$ ) is low, and as a result of the anodic iron dissolution, a siderite corrosion layer is formed on the surface of the alloy [12,13]. $\mathrm{CO}_{2}$ corrosion sensitively depends on alloy composition, environmental factors such as temperature, partial $\mathrm{CO}_{2}$ pressure, flow conditions, and protective corrosion scales in the processing of geothermal energy. [18-26]. The concentration of $\mathrm{H}_{2} \mathrm{~S}$ has a significant impact on the defensive ability of the sulfide film formed. Due to the increase of $\mathrm{H}_{2} \mathrm{~S}$ concentration, a very unstable film formed at a $\mathrm{pH}$ level of 3-5 that does not have any contribution in combating corrosion. With the increasing absorption of $\mathrm{H}_{2} \mathrm{~S}$, the film formed is very loose at a $\mathrm{pH}$ range of 3-5 and does not contribute to the inhibiting effect of corrosion [27]. The $\mathrm{pH}$ of the solution played an important role on the nature and composition of the corrosion product. Iron dissolves at a lower $\mathrm{pH}$ level (1-2), and no precipitation of FeS occurs on the metal surface, as the solubility of FeS is very high in that $\mathrm{pH}$ range. Here, the acceleration of Fe dissolution is due to $\mathrm{H}_{2} \mathrm{~S}$. The formation of a protective film of iron sulfide (FeS) on the surface of the electrode is due to the inhibitive effects of $\mathrm{H}_{2} \mathrm{~S}$ at a pH level between 3 and 5 [28]. As the solubility of $\mathrm{H}_{2} \mathrm{~S}$ in water is three times more than that of $\mathrm{CO}_{2}$ gas, the acid formed by $\mathrm{H}_{2} \mathrm{~S}$ dissociation is around three times weaker than carbonic acid $\left(\mathrm{H}_{2} \mathrm{CO}_{3}\right)$ [29]. Therefore, the effect of $\mathrm{H}_{2} \mathrm{~S}$ gas on reducing the $\mathrm{pH}$ of the solution is nearly the same as that of $\mathrm{CO}_{2}$ gas. Unlike dissolved $\mathrm{CO}_{2}$, to become an acid, dissolved $\mathrm{H}_{2} \mathrm{~S}$ does not need to undergo the slow hydration process. $\mathrm{H}_{2} \mathrm{~S}$ reduces the solution $\mathrm{pH}$ in an $\mathrm{H}_{2} \mathrm{~S}$-driven environment when it serves as a weak acid such as carbonic acid. Similar to carbonic 
acid $\left(\mathrm{H}_{2} \mathrm{CO}_{3}\right)$, it may also increase the corrosion rate by providing an additional cathodic reaction generated by the following equation [30].

$$
\mathrm{H}_{2} \mathrm{~S}+\mathrm{e}^{-} \rightarrow \mathrm{H}+\mathrm{HS}^{-}
$$

However, this direct reduction of $\mathrm{H}_{2} \mathrm{~S}$ is only possible if the amount of $\mathrm{H}_{2} \mathrm{~S}$ is too high, which means that either it needs to be the $\mathrm{H}_{2} \mathrm{~S}$ controlled system (sour regime) or the $\mathrm{CO}_{2} / \mathrm{H}_{2} \mathrm{~S}$ mix system [10]. In comparison, a high $\mathrm{H}_{2} \mathrm{~S}$ concentration is often correlated with elemental sulfur, and relatively little is understood about the dynamic interactions that take place in the presence of the elemental form of sulfur. In the presence of low $\mathrm{H}_{2} \mathrm{~S}$ concentration in an environment of $\mathrm{CO}_{2}$, the formation of the carbonate scale $\left(\mathrm{FeCO}_{3}\right)$ is affected by the iron sulfide ( $\mathrm{FeS}$ ) film [30]. This aspect of the environment or system is of concern, because it would appear that the iron sulfide film is removed more easily from the pipe wall than the iron carbonate scales. The protective film can be removed in the turbulent situations, which lead to an increase in the rate of corrosion. In the $\mathrm{CO}_{2} / \mathrm{H}_{2} \mathrm{~S}$ system, the kinetics of film formation is complex and still not well known. Under these circumstances, the face of the surface scale will not only depend on the corresponding solubility of iron carbonates and iron sulfides but also on the mechanisms of the twoscale formation [31]. The aim of this work is to provide a systematic understanding of the corrosion behavior of 304 stainless steel in $\mathrm{CO}_{2}$ and $\mathrm{CO}_{2}-\mathrm{H}_{2} \mathrm{~S}$ environments in the presence of $\mathrm{NaCl}$. By a combination of potentiostatic measurements and potentiodynamic polarization, in the presence and absence of $\mathrm{H}_{2} \mathrm{~S}$, the influence of $\mathrm{pH}$ value on the corrosion behavior of $304 \mathrm{SS}$ was assessed. EIS was deployed to investigate the synergistic effect of $\mathrm{CO}_{2}$ and $\mathrm{CO}_{2}-\mathrm{H}_{2} \mathrm{~S}$. SEM was employed to see the changes of the surface nature after corrosion in various environments.

\section{Experimental Procedure}

\subsection{Materials and Methods}

The test was carried out on the polished 304 ASS specimens. Sample surfaces were polished using 120,180,1/0, and 2/0 grade emery paper and finally by a cloth polisher. A simulation environment was deployed in the lab scale similar to oil corrosion industries. Throughout electrochemical tests, $\mathrm{H}_{2} \mathrm{~S}(200 \mathrm{ppm}), \mathrm{CO}_{2}(200 \mathrm{ppm})$, or a mixed gas $\left(\mathrm{H}_{2} \mathrm{~S}\right.$ (200 ppm)/ $/ \mathrm{CO}_{2}$ (200 ppm): 1/1) was purged into the simulated solutions of deionized water, sodium chloride and acetic acid under supervision; a constant $40 \mathrm{~mL} / \mathrm{min}$ flow rate was maintained to attain point of saturation.

\subsection{Potentiodynamic Polarization}

Potentiodynamic polarization and an Electrochemical Impedance Spectroscopy (EIS) test of all the samples were conducted in four different test solutions with varying compositions. The solutions were: $3.5 \% \mathrm{NaCl}$ with three different $\mathrm{pH}$ levels ( $\mathrm{pH}$ at 3,7 , 10), $3.5 \% \mathrm{NaCl}+$ saturated $\mathrm{CO}_{2}$ with three different $\mathrm{pH}$ levels ( $\mathrm{pH}$ at $\left.3,7,10\right)$, and $3.5 \% \mathrm{NaCl}+$ saturated $\mathrm{CO}_{2}+\mathrm{H}_{2} \mathrm{~S}$ with three different $\mathrm{pH}$ levels $(\mathrm{pH} 3,7,10)$. After performing a potentiodynamic polarization experiment, the samples were examined for visible effect of $\mathrm{CO}_{2}$ and sodium thiosulfate with the help of Scanning Electron Microscope (SEM).

Potentiodynamic polarization experiments were carried out on the range of -0.6 to $0.6 \mathrm{~V}$ vs. SCE with a scan rate of $1 \mathrm{mV} / \mathrm{s}$ on all the samples using a Gamry Potentiostatic PC/750 (Metrohm AG, Herisau, Switzerland). All the four samples were polished with emery paper and later cloth polished. After polishing, with the help of acetone and ethanol solution, all the 304 ASS samples were cleaned. A standard three electrode system was deployed to measure the $i_{\text {corr }}$ and $E_{\text {corr }}$ values of the bar sample. Here, test specimens were used as a working electrodes, graphite was used as an auxiliary electrode and a saturated calomel electrode (SCE) is reflected as the reference electrode. All the tests were performed at room temperature in previously mentioned solutions. The surface area was varied for all the samples that are exposed to the solutions. 


\subsection{Electrochemical Impedance Spectroscopy (EIS)}

For Electrochemical Impedance Spectroscopy (EIS), a three-electrode corrosion cell was used. The experiments were performed using $100 \mathrm{mV}$ AC voltage RMS (root-meansquare) and $0 \mathrm{~V} D C$ in the frequency range of $0.01-10 \mathrm{kHz}$ at 10 cycles/decade. Nyquist and Bode plots were obtained by measuring the phase angle and absolute impedance at each frequency point. Impedance data were analyzed with the help of a suitable equivalent electrical circuit utilizing the real and imaginary components using a simplex fit model supplied with the EIS software for impedance data interpretation. Gamry Echem Analyst software was used here.

\subsection{SEM Analysis}

In order to study the surface morphology of $304 \mathrm{SS}$ after the potentiodynamic polarization experiment in different solution, scanning electron microscope (SEM) was used. The surface characterization studies of all the samples were carried out using Model JEOL JSM6360 SEM (JEOL Ltd., Akishima, Tokyo, Japan). In this present study, 200× magnification was used.

\subsection{Raman Spectroscopy}

Raman spectroscopy helps with determining the composition of steel surfaces and hence corrosion behavior. The Raman spectrum of the samples was measured using a Raman spectrometer LabRAM HR800 (HORIBA Jobin Yvon, Paris, France) with an incident laser light at a wavelength of $514.5 \mathrm{~nm}$. Raman bands were calibrated using the $520 \mathrm{~cm}^{-1}$ band from Si. The Raman spectra were taken at three appropriate points on each sample in the range of 100 to $2000 \mathrm{~cm}^{-1}$.

\section{Results and Discussion}

\subsection{Potentiodynamic Polarization Analysis}

The potentiodynamic polarization experiments of a 304 stainless steel sample were done in different simulated solutions, and the obtained results are shown in Figure 1. The $\mathrm{i}_{\text {corr }}$ and $\mathrm{E}_{\mathrm{corr}}$ values obtained from these curves by Tafel's extrapolation methods are tabulated in Table 1. It is noticeable that the $i_{\text {corr }}$ value of the $304 \mathrm{SS}$ sample in $3.5 \% \mathrm{NaCl}$ with saturated $\mathrm{CO}_{2}$ solution is lower compared to any of the other solutions, $3 \times 10^{-8} \mathrm{~A} / \mathrm{cm}^{2}$, $1 \times 10^{-7} \mathrm{~A} / \mathrm{cm}^{2}$, and $2 \times 10^{-7} \mathrm{~A} / \mathrm{cm}^{2}$, considering $\mathrm{pH}$ values of 10,7 , and 3 , respectively. It is also found that the values of $\mathrm{i}_{\text {corr }}$ can be ranked from low to high: in $\mathrm{CO}_{2}, \mathrm{NaCl}$, and $\mathrm{CO}_{2}+\mathrm{H}_{2} \mathrm{~S}$ solutions. In $304 \mathrm{SS}$, the processes of corrosion are predominantly controlled by the formation of a thick oxide film that inhibits the diffusion of destructive ions into the materials. It is clear that in case of $\mathrm{CO}_{2}$ solution at higher $\mathrm{pH}$, it forms a stable iron carbonate film, which also has a positive effect on the $\mathrm{E}_{\text {corr }}$ value of this sample. In $\mathrm{CO}_{2}+\mathrm{H}_{2} \mathrm{~S}$ solution with $\mathrm{pH} \approx 3, \mathrm{H}_{2} \mathrm{~S}$ and $\mathrm{Cl}$ - were thought to cause $304 \mathrm{SS}$ pitting corrosion at the inclusion of MnS [32]. Ikeda et al. [33] in their research reported that with 9-25 wt\% $\mathrm{Cr}$, the alloy becomes nearly resistant to $\mathrm{CO}_{2}$ corrosion, as it is in our case with $304 \mathrm{SS}$ (16-18.5 wt\% Cr) possessing the lowest $\mathrm{i}_{\text {corr }}$ in $\mathrm{CO}_{2}$ solution. Furthermore, in $\mathrm{H}_{2} \mathrm{~S}+\mathrm{CO}_{2}$ solution, $304 \mathrm{SS}$ displays higher $\mathrm{i}_{\text {corr }}$ compared to the other two solutions. It is believed that the synergistic effect of $\mathrm{CO}_{2}$ and $\mathrm{H}_{2} \mathrm{~S}$ is causing relatively more serious corrosion rather than helping in prevention from protective corrosion products. 

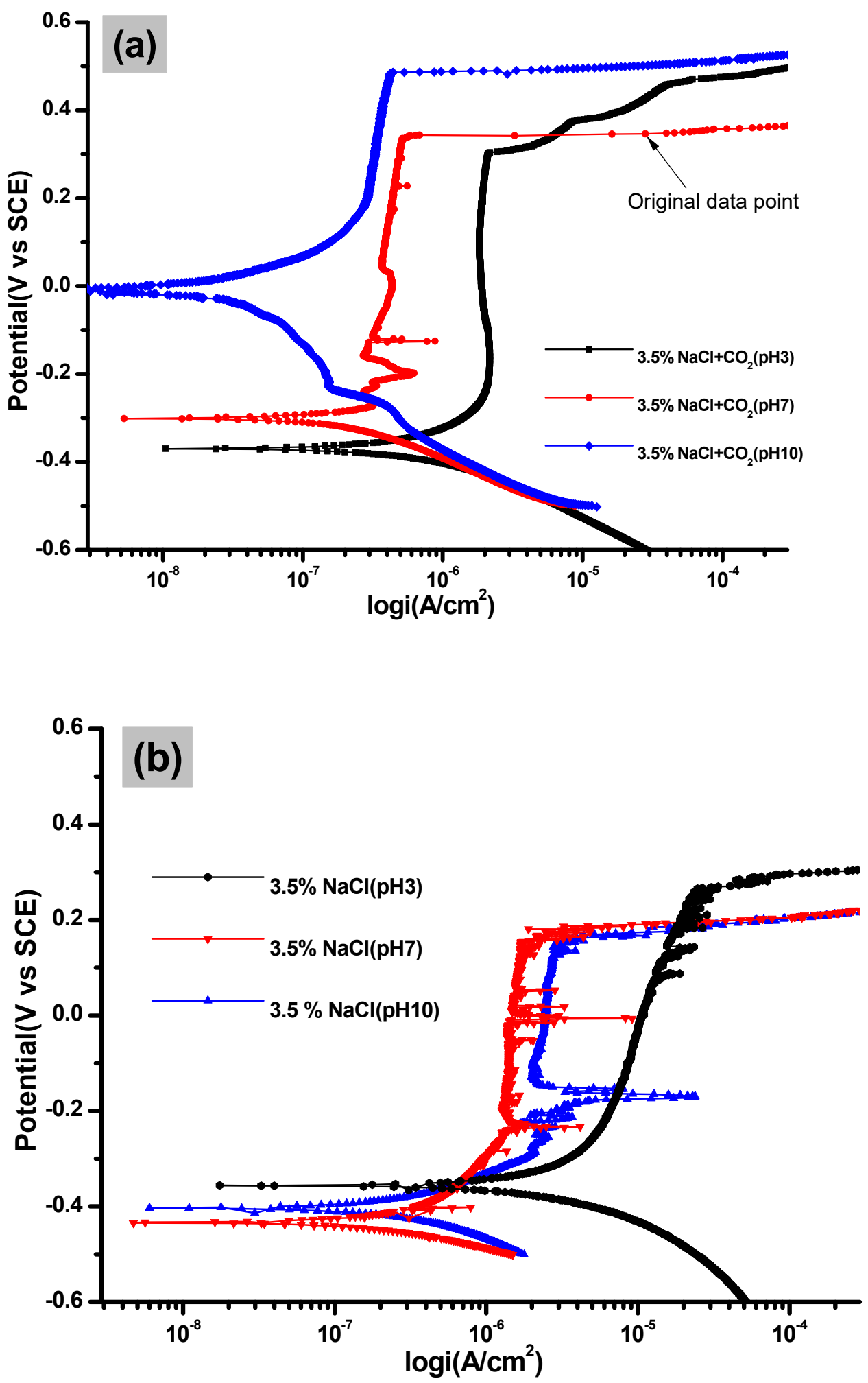

Figure 1. Cont. 


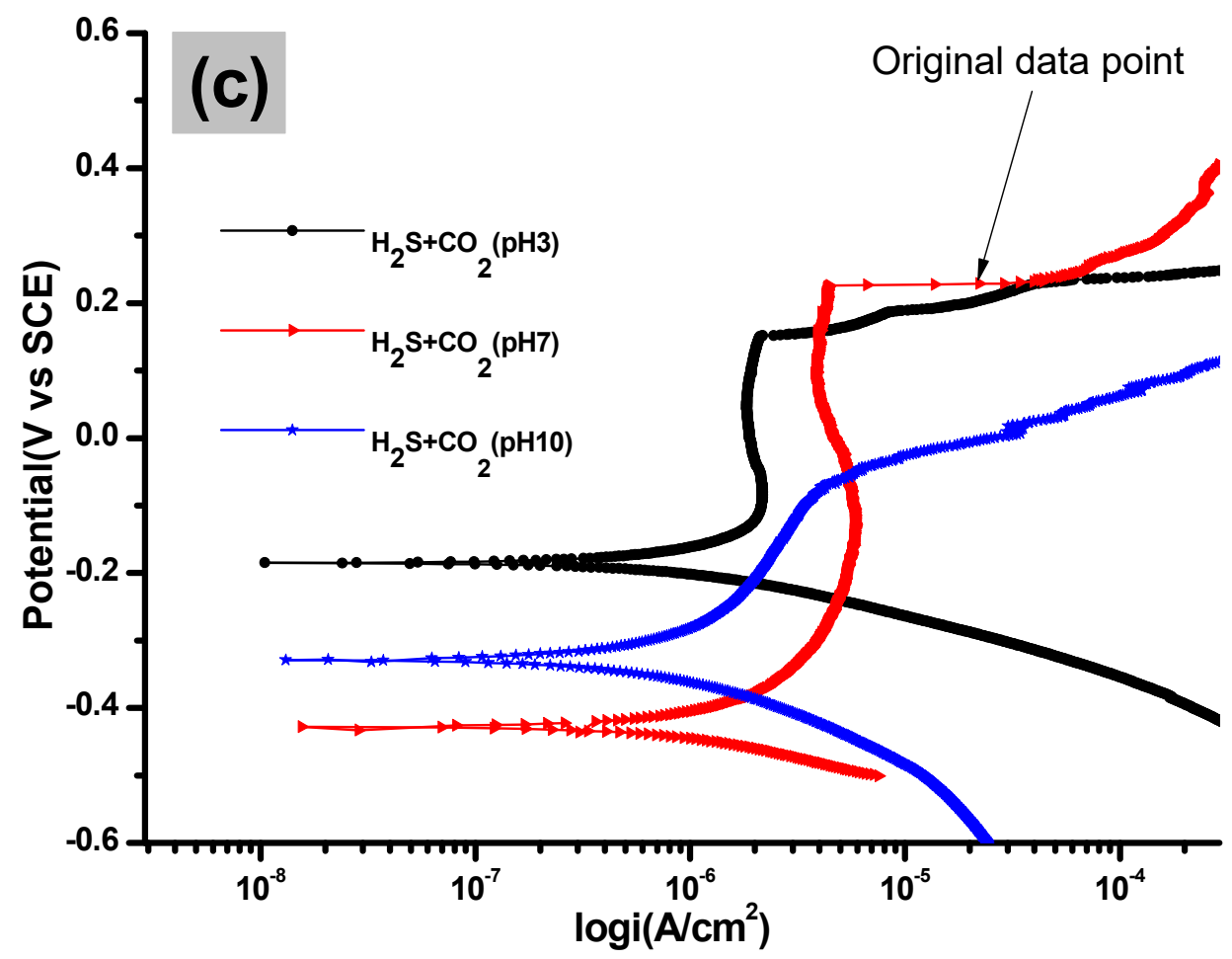

Figure 1. Potentiodynamic polarization plots with different $\mathrm{pH}$ values in (a) $3.5 \% \mathrm{NaCl}+\mathrm{CO}_{2}$, (b) $3.5 \% \mathrm{NaCl}$, and (c) $\mathrm{CO}_{2}+\mathrm{H}_{2} \mathrm{~S}$ solutions.

Table 1. Potentiodynamic polarization results in different solutions with different $\mathrm{pH}$ values.

\begin{tabular}{|c|c|c|c|}
\hline Solution & $\mathrm{pH}$ & $i_{\text {corr }}\left(\mathrm{A} \mathrm{cm}^{-2}\right)$ & $E_{\text {corr }}(V)$ \\
\hline \multirow{3}{*}{$3.5 \% . \mathrm{NaCl}+\mathrm{CO}_{2}$} & 3 & $2 \times 10^{-7}$ & -0.3633 \\
\hline & 7 & $1 \times 10^{-7}$ & -0.3013 \\
\hline & 10 & $3 \times 10^{-8}$ & -0.0073 \\
\hline \multirow{3}{*}{$3.5 \% \mathrm{NaCl}$} & 3 & $6 \times 10^{-7}$ & -0.3699 \\
\hline & 7 & $3 \times 10^{-6}$ & -0.4422 \\
\hline & 10 & $2 \times 10^{-6}$ & -0.4282 \\
\hline \multirow{3}{*}{$\mathrm{CO}_{2}+\mathrm{H}_{2} \mathrm{~S}$} & 3 & $2 \times 10^{-5}$ & -0.1313 \\
\hline & 7 & $6 \times 10^{-6}$ & -0.4259 \\
\hline & 10 & $3 \times 10^{-6}$ & -0.3291 \\
\hline
\end{tabular}

\subsection{EIS Study}

Figures 2 and 3 show a Bode magnitude plot and Bode phase plot, respectively. The Bode magnitude plot of all the samples shows two distinct regions. In the low and higher frequency region, the Bode magnitude plot exhibits constant $\log |Z|$ values vs. $\log (f)$ with a phase angle near $0^{0}$. This is due to the response of the solution resistance. The $\log |\mathrm{Z}|$ of a $\mathrm{CO}_{2}$-containing sample stabilized at a higher frequency range, whereas the $\mathrm{CO}_{2}+\mathrm{H}_{2} \mathrm{~S}$ containing sample stabilized at the lowest $\log |\mathrm{Z}|$ value. In the wide-ranging $(1 \mathrm{kHz}-100 \mathrm{mHz})$ frequency, the spectra display a linear slope of about -1 . This shows the capacitive characteristic of the surface film [34,35]. In the low-frequency range, the phase angle of three samples decreases, indicating the contribution of surface film resistance to the impedance. 

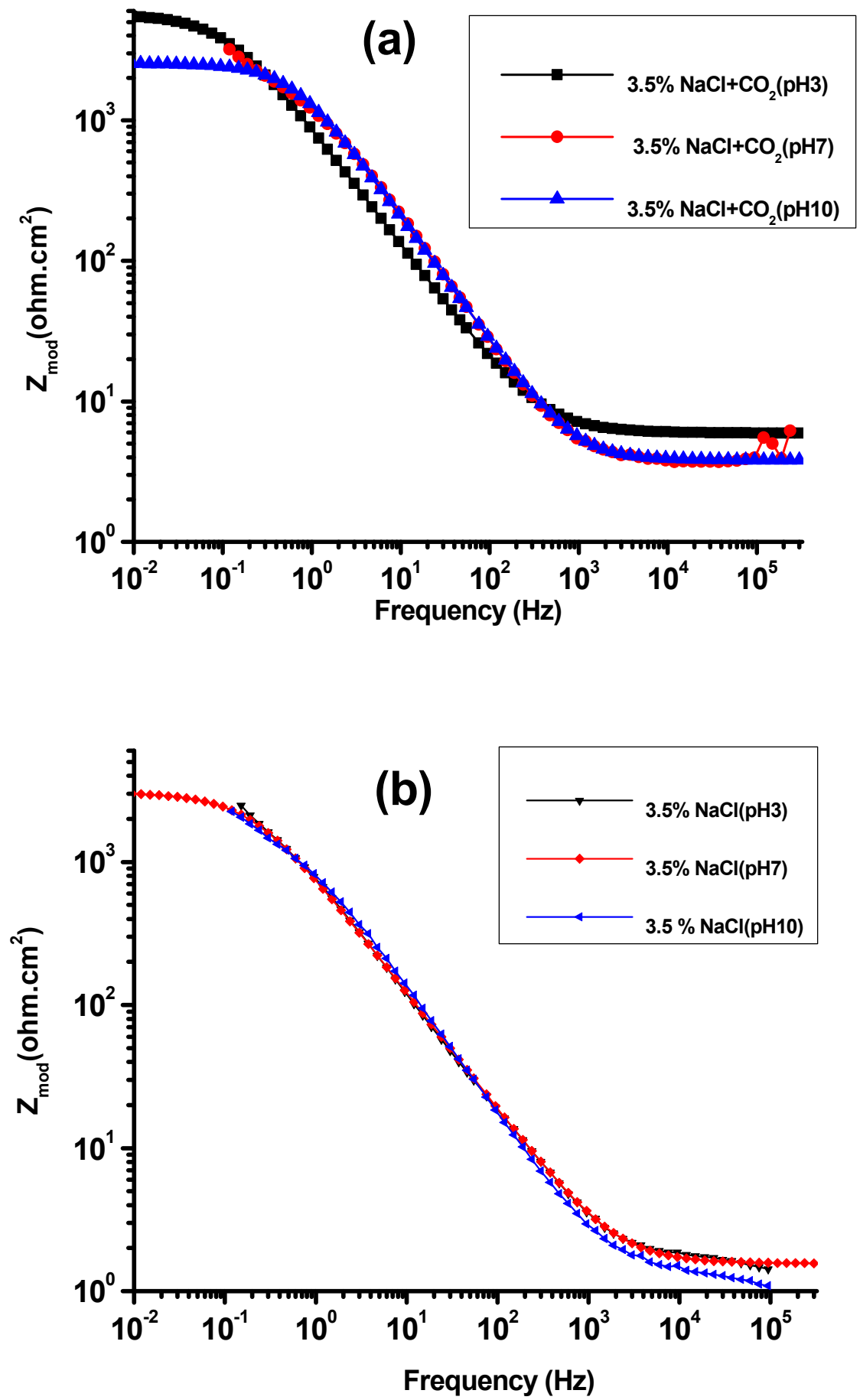

Figure 2. Cont. 


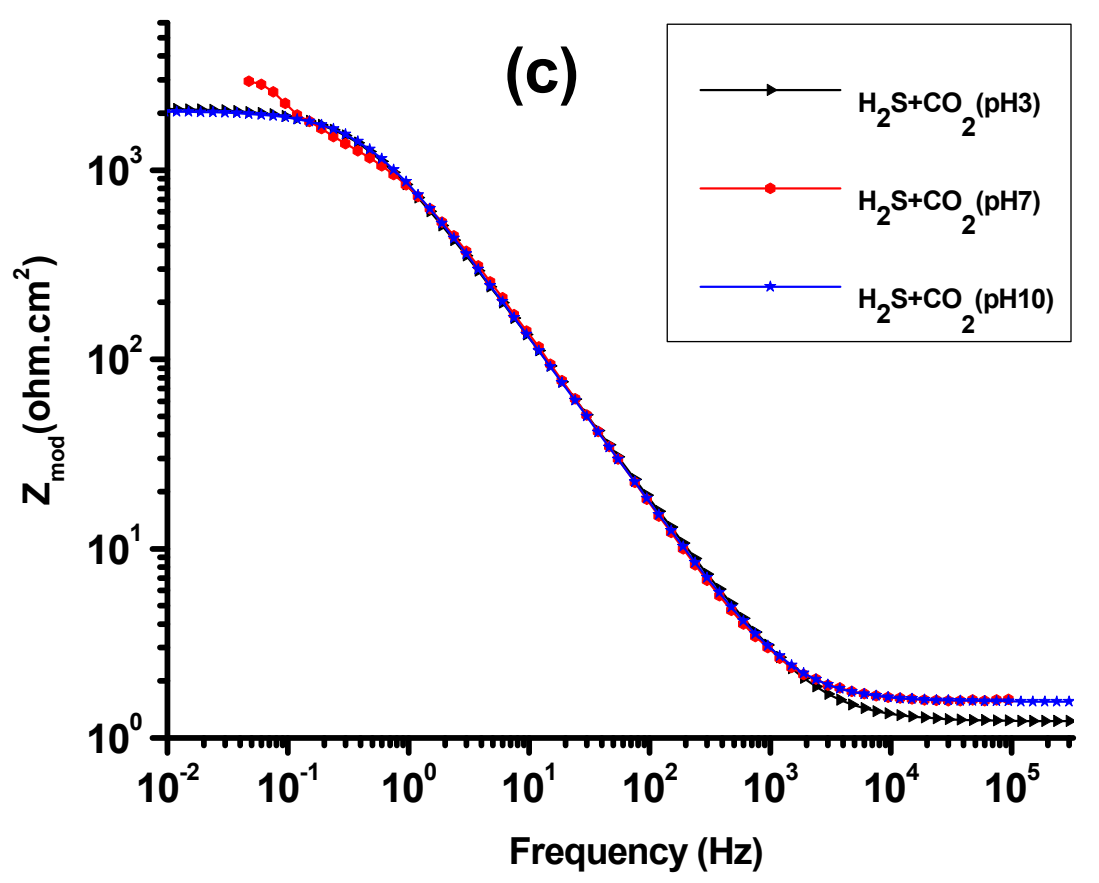

Figure 2. Bode magnitude plots in different solutions with different $\mathrm{pH}$ values: (a) $3.5 \% \mathrm{NaCl}+\mathrm{CO}_{2}$, (b) $3.5 \% \mathrm{NaCl}$, and (c) $\mathrm{CO}_{2}+\mathrm{H}_{2} \mathrm{~S}$ solution.

Figure 4 shows the Nyquist plots of 304 stainless steel under different solutions conditions. In the Nyquist plot, a higher radius of imaginary versus real resistance is related to the corrosion resistance of the alloy. The $304 \mathrm{SS}$ sample in $\mathrm{CO}_{2}$ solution shows the highest area under the curve compared to other sample, which indicates a higher polarization resistance value. The higher polarization resistance value is related to the higher corrosion resistance of the sample, which is also supported by the corrosion data, i.e., $\mathrm{i}_{\text {corr }}$ value. The $304 \mathrm{SS}$ sample in $\mathrm{CO}_{2}+\mathrm{H}_{2} \mathrm{~S}$ exhibits the lowest area under the curve. So, naturally, its corrosion resistance is weaker when compared to other samples. For all the samples, the area under the curve decreases with the decreasing of $\mathrm{pH}$. This illustrates that in the proposed environment, the formed film has been disbanded and the protection is lost, which in turn corrodes the surface beneath at a higher rate.

Additionally, the EIS results were analyzed and fitted with appropriate equivalent circuits (EC) using a Gamry Potentiostatic PC/750 (Metrohm AG, Herisau, Switzerland) in order to gather more information about the corrosion mechanism. Multiple equivalent circuits were used to analyze the EIS data. The equivalent circuit with a minimum error value was chosen in this study and can be seen in Figure 5, which has been reported by other research as well [36].

The equivalent circuit parameters in Figure 5 are the solution resistance $\left(R_{\mathrm{S}}\right)$, the capacitance of passive film $\left(Q_{\mathrm{f}}\right)$, the resistance of passive film $\left(R_{\mathrm{f}}\right)$, the capacitance of an electrical double layer at interfaces $\left(Q_{\mathrm{dl}}\right)$, and the charge transfer resistance $\left(R_{t}\right)$. The constant phase element, CPE $(Q)$, is usually used for uneven current distribution at the surface or increased surface roughness. The impedance of CPE is given by:

$$
Z_{Q}=Y_{0}(j \omega)^{-n}
$$

where $Y_{0}$ is a modulus, $j^{2}=-1, \omega$ is the angular frequency, and $n$ is an empirical exponent between 0 and 1 . The property of CPE depends on the value of $n$. CPE acts as a pure capacitor for $\mathrm{n}=1$, as a resistor when $\mathrm{n}=0$, and as a Warburg impedance when $n=0.5$. Table 2 represents the values of equivalent circuit parameters for each solution. In $3.5 \%$ $\mathrm{NaCl}$ solution, the smaller impedance arc represents that the corrosion resistance decreases due to $\mathrm{Cl}^{-}$concentration. It has been seen that the value of $R_{\mathrm{f}}$ decreases in a $\mathrm{CO}_{2}+\mathrm{H}_{2} \mathrm{~S}$ - 
containing environment. This indicates that the degradation of passive film is highest in this solution. $R_{\mathrm{t}}$ values change in a similar manner with the values of $R_{\mathrm{f}}$, and they also decreased as the $\mathrm{Cl}^{-}$concentration increased. The solution $\left(R_{\mathrm{S}}\right)$ is in relation with the corrosion resistance property. Chi squared indicates the goodness of fit. From the data, it is quite clear that it fits very well with the data.
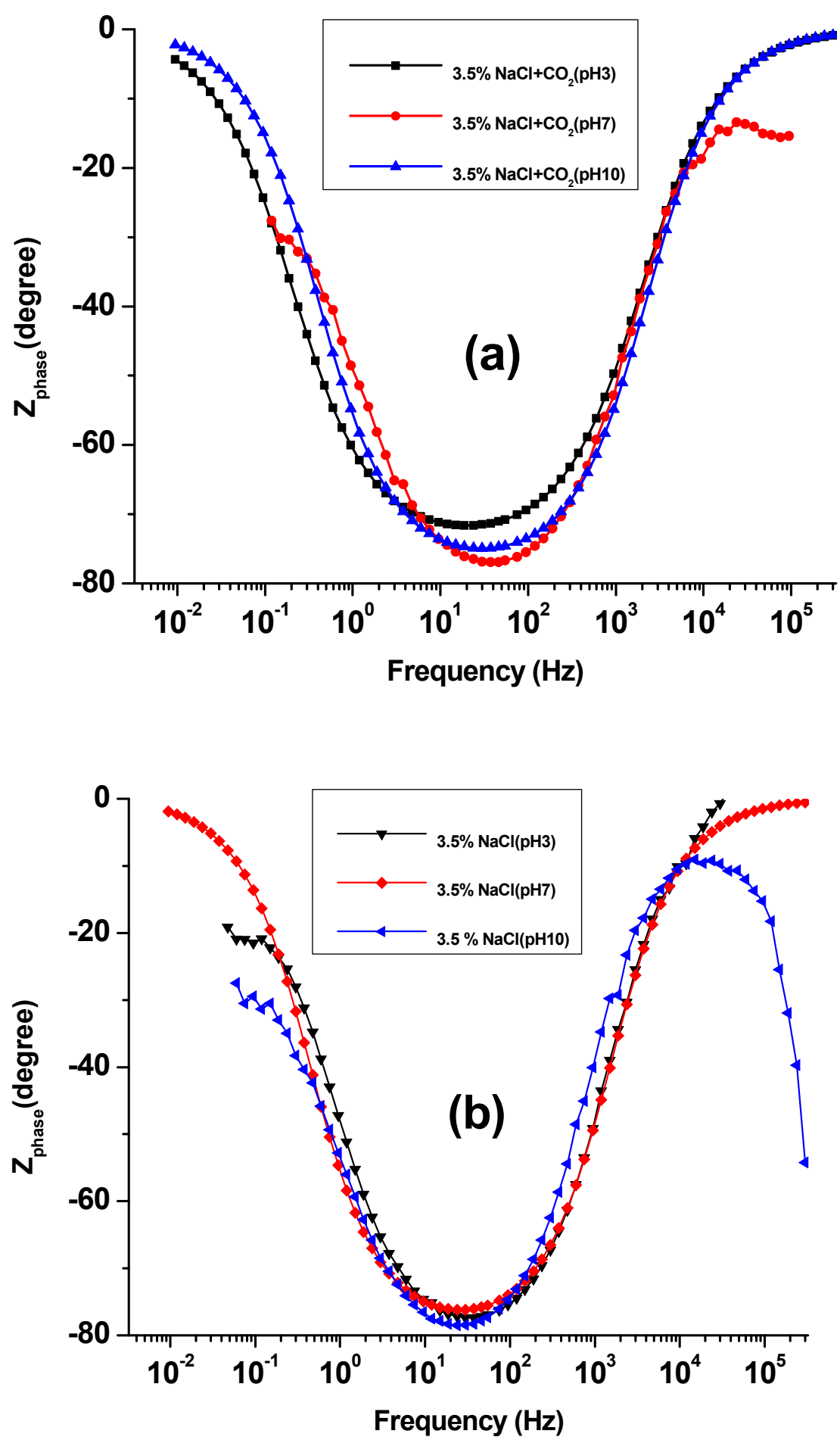

Figure 3. Cont. 


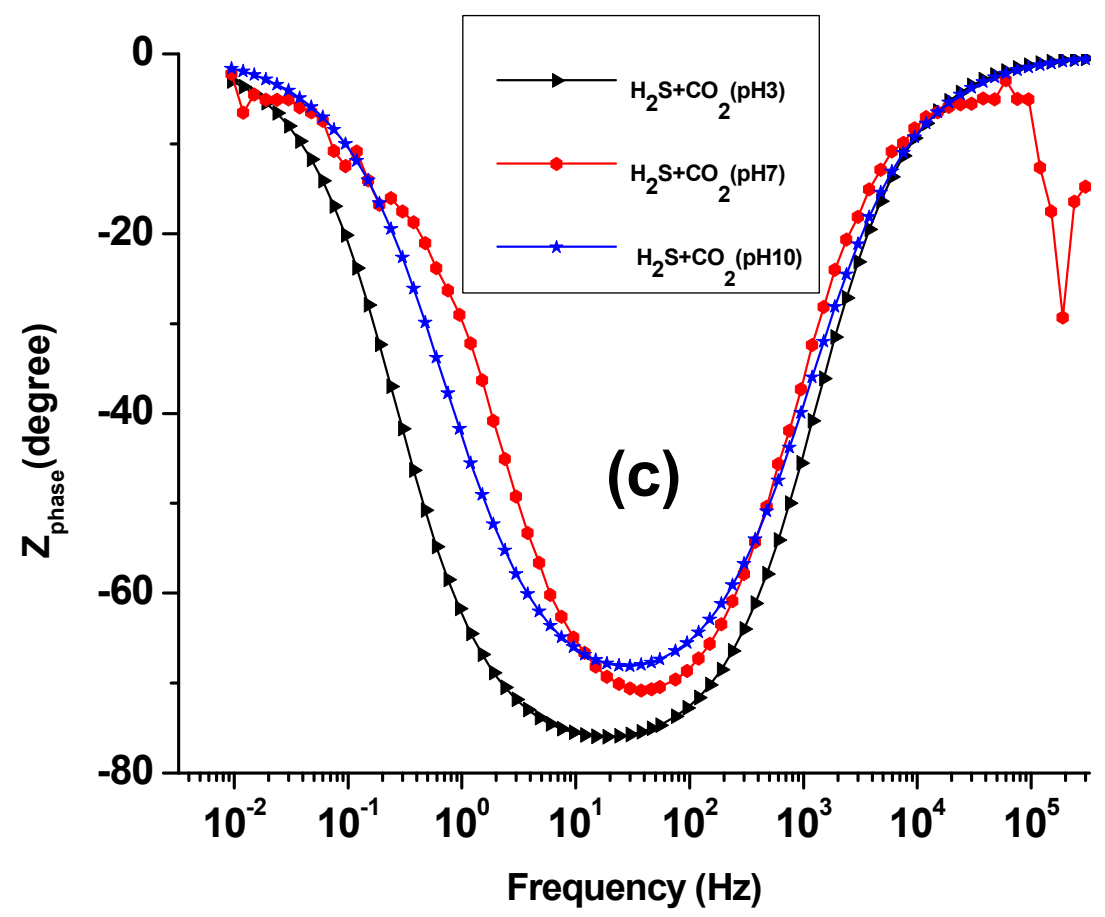

Figure 3. Phase magnitude plots in different solutions with different pH levels: (a) $3.5 \% \mathrm{NaCl}+\mathrm{CO}_{2}$, (b) $3.5 \% \mathrm{NaCl}$, and (c) $\mathrm{CO}_{2}+\mathrm{H}_{2} \mathrm{~S}$ solution

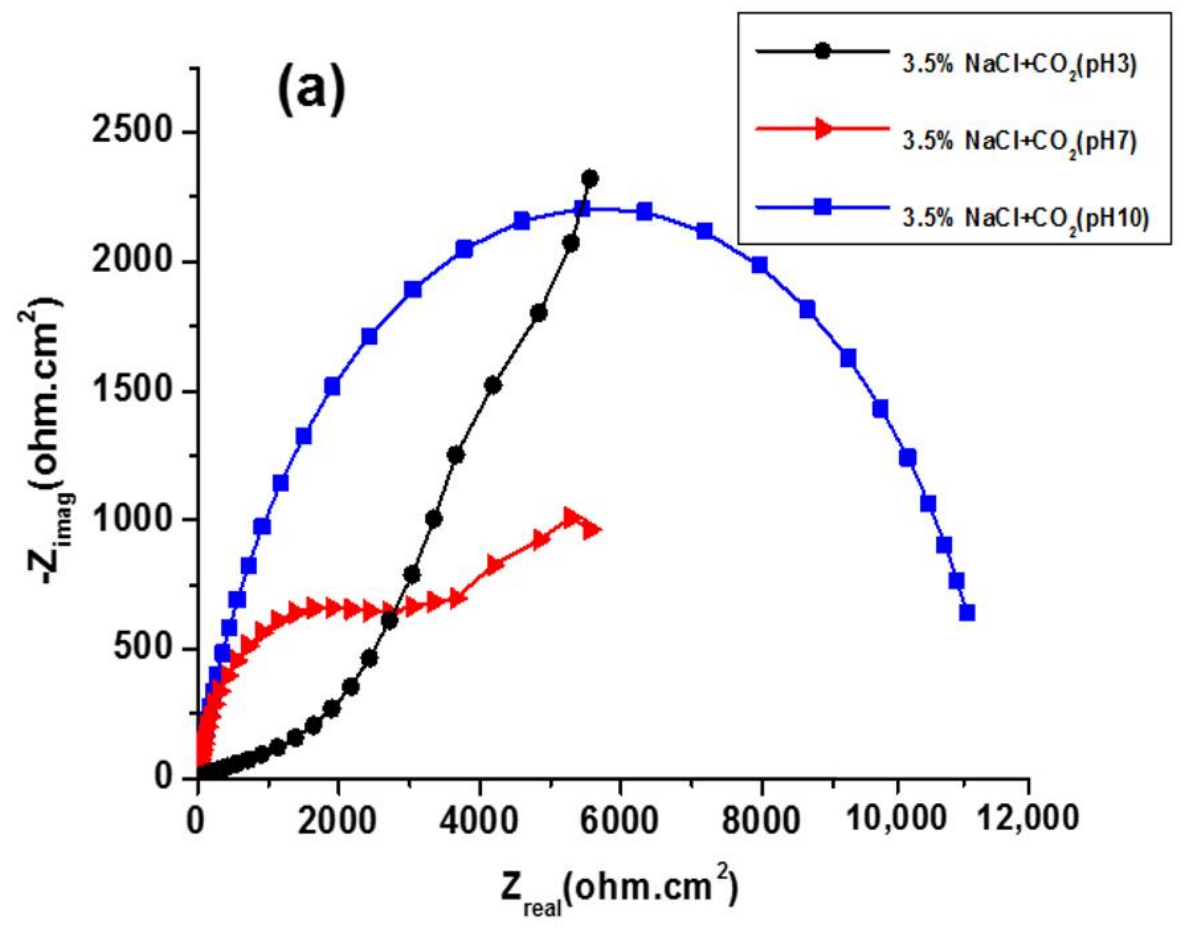

Figure 4. Cont. 

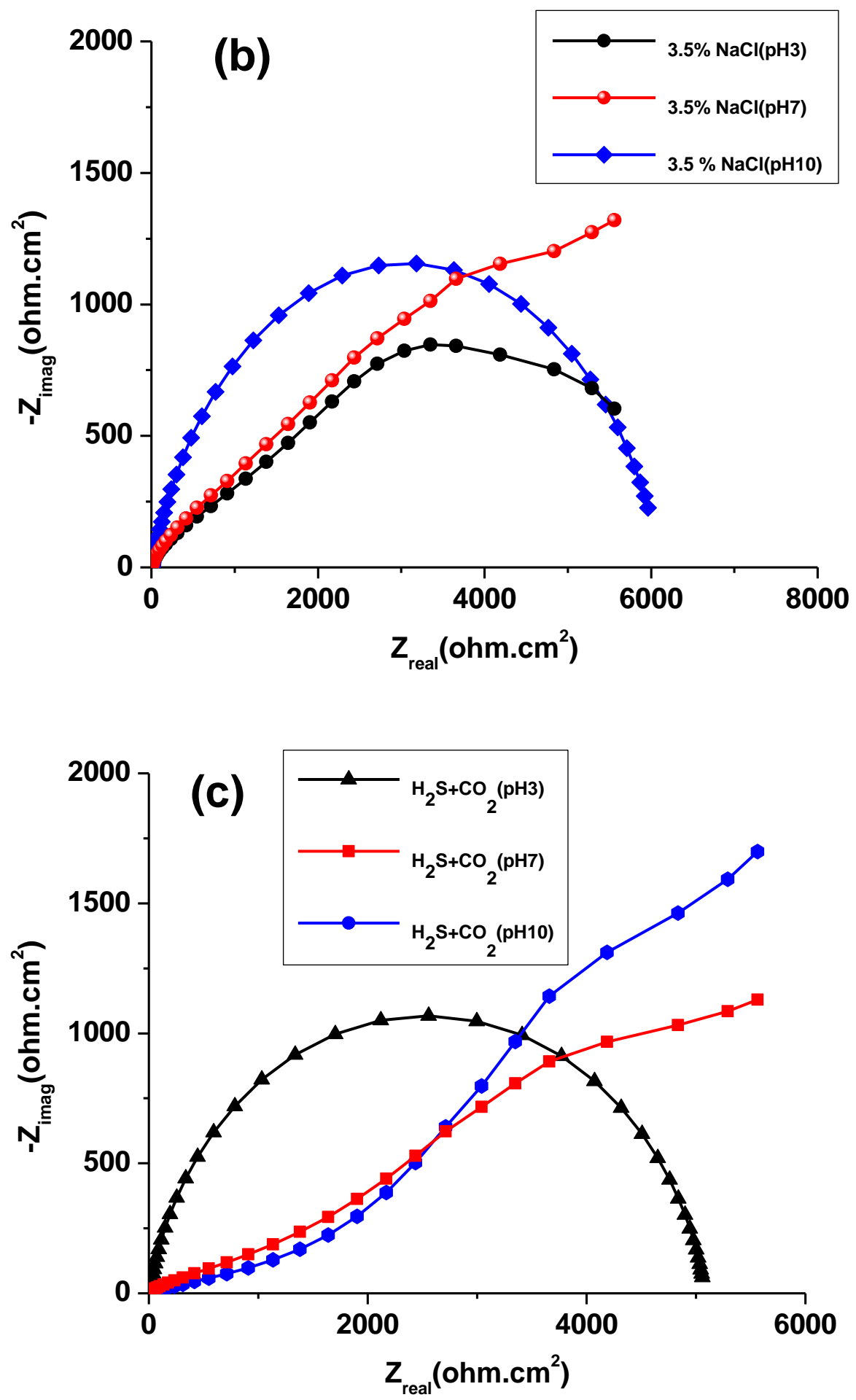

Figure 4. Nyquist plots in different solutions with different $\mathrm{pH}$ levels: (a) $3.5 \% \mathrm{NaCl}+\mathrm{CO}_{2}$, (b) $3.5 \%$ $\mathrm{NaCl}$, and (c) $\mathrm{CO}_{2}+\mathrm{H}_{2} \mathrm{~S}$ solution. 


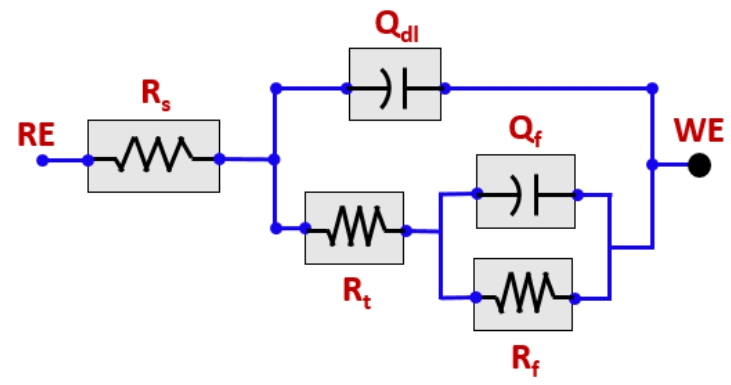

Figure 5. Equivalent circuit for simulating EIS results.

Table 2. Electrochemical Impedance Spectroscopy results in different solutions with different $\mathrm{pH}$ values.

\begin{tabular}{|c|c|c|c|c|c|c|c|}
\hline Solution & $\mathrm{pH}$ & $\underset{\left(\mathrm{ohm}-\mathrm{cm}^{2}\right)}{R_{\mathrm{s}}}$ & $\underset{\left(\mathrm{k} . \mathrm{ohm} \cdot \mathrm{cm}_{\mathrm{t}}\right)}{R^{2}}$ & $\underset{\text { (k.ohm.cm }}{R_{\mathrm{f}}}$ & $\underset{\left(\mathrm{F} . \mathrm{cm}^{2}\right)}{Q_{\mathrm{dl}}}$ & $Q_{\mathrm{f}}\left(\mathrm{F} \cdot \mathrm{cm}^{2}\right)$ & $\begin{array}{l}X^{2}, \text { chi } \\
\text { Squared }\end{array}$ \\
\hline \multirow{3}{*}{$\mathrm{CO}_{2}$} & 3 & 51.2 & 4.96 & 5.86 & 1362 & $10.43 \times 10^{-4}$ & $5.14 \times 10^{-3}$ \\
\hline & 7 & 39.9 & 5.83 & 6.80 & 2146 & $12.26 \times 10^{-4}$ & $4.43 \times 10^{-3}$ \\
\hline & 10 & 61.6 & 10.41 & 12.40 & 4150 & $14.56 \times 10^{-4}$ & $3.15 \times 10^{-3}$ \\
\hline \multirow{3}{*}{$\begin{array}{l}3.5 \% \\
\mathrm{NaCl}\end{array}$} & 3 & 41.6 & 4.61 & 4.78 & 3186 & $6.02 \times 10^{-4}$ & $5.23 \times 10^{-3}$ \\
\hline & 7 & 52.9 & 5.10 & 4.90 & 4195 & $6.98 \times 10^{-4}$ & $4.31 \times 10^{-3}$ \\
\hline & 10 & 71.6 & 5.11 & 5.20 & 6282 & $9.84 \times 10^{-4}$ & $4.77 \times 10^{-3}$ \\
\hline \multirow{3}{*}{$\begin{array}{c}\mathrm{CO}_{2}+ \\
\mathrm{H}_{2} \mathrm{~S}\end{array}$} & 3 & 36.5 & 3.29 & 3.45 & 3845 & $3.98 \times 10^{-4}$ & $5.99 \times 10^{-3}$ \\
\hline & 7 & 55.6 & 4.15 & 4.01 & 4288 & $4.98 \times 10^{-4}$ & $4.35 \times 10^{-3}$ \\
\hline & 10 & 61.6 & 4.59 & 4.24 & 6211 & $5.34 \times 10^{-4}$ & $4.23 \times 10^{-3}$ \\
\hline
\end{tabular}

\subsection{SEM Analysis}

Figure 6 represents the SEM images of the samples after a corrosion test in different electrolytes with the same $\mathrm{pH}$ value of 7 . From the micrograph, it is quite clear that the pit formation is higher in the $\mathrm{CO}_{2}+\mathrm{H}_{2} \mathrm{~S}$ environment. This is because the iron sulfide (FeS) film, which is formed due to the presence of $\mathrm{H}_{2} \mathrm{~S}$, interferes with the formation of the carbonate scale $\left(\mathrm{FeCO}_{3}\right)$. This iron sulfide film can be more easily removed from the pipeline than the iron carbonate scale, which causes an increase in the corrosion rate. Whereas, a clear protective layer can be seen from the SEM images, which is due to the formation of $\mathrm{FeCO}_{3}$ in an only $\mathrm{CO}_{2}$ environment. In a chloride environment, a uniform corrosion and little bit of pitting formation can be seen. The corrosion data also support the same.

\subsection{Raman Spectroscopy}

In Figure 7a, the sample corroded in $\mathrm{NaCl}$ shows a Raman peak in two bands (at 250 and $1250 \mathrm{~cm}^{-1}$ ), due to the formation of $\mathrm{FeOOH}$. This peak of band is also shown at $400 \mathrm{~cm}^{-1}$ due to the formation of magnetite $\left(\mathrm{Fe}_{3} \mathrm{O}_{4}\right)$. A low-density peak is also shown at $540 \mathrm{~cm}^{-1}$, which indicates the formation of $\mathrm{Fe}(\mathrm{OH})_{2}[37,38]$.

Figure $7 \mathrm{~b}$ presents the Raman spectroscopy curve of the sample corroded in $\mathrm{NaCl}$ solution saturated with $\mathrm{CO}_{2}$. $\mathrm{FeCO}_{3}$ and $\mathrm{Fe}_{3} \mathrm{C}$ are the typical compositions of corrosion product during the $\mathrm{CO}_{2}$ corrosion process shown in peaks in two bands $\left(375,1400 \mathrm{~cm}^{-1}\right.$ and $400,600 \mathrm{~cm}^{-1}$ ), while $\mathrm{Fe}_{3} \mathrm{C}$ is not the corrosion product but the remainder of ASS304 after the selective dissolution of austenite $[39,40] . \mathrm{FeCO}_{3}$ is very protective in nature. In the absence of $\mathrm{H}_{2} \mathrm{~S}, \mathrm{FeCO}_{3}$ could nucleate and grow rapidly around $\mathrm{Fe}_{3} \mathrm{C}$ and form a $\mathrm{FeCO}_{3}$ scale, which gives better bonding stress to the steel and fastened $\mathrm{Fe}_{3} \mathrm{C}$ on the steel surface. 

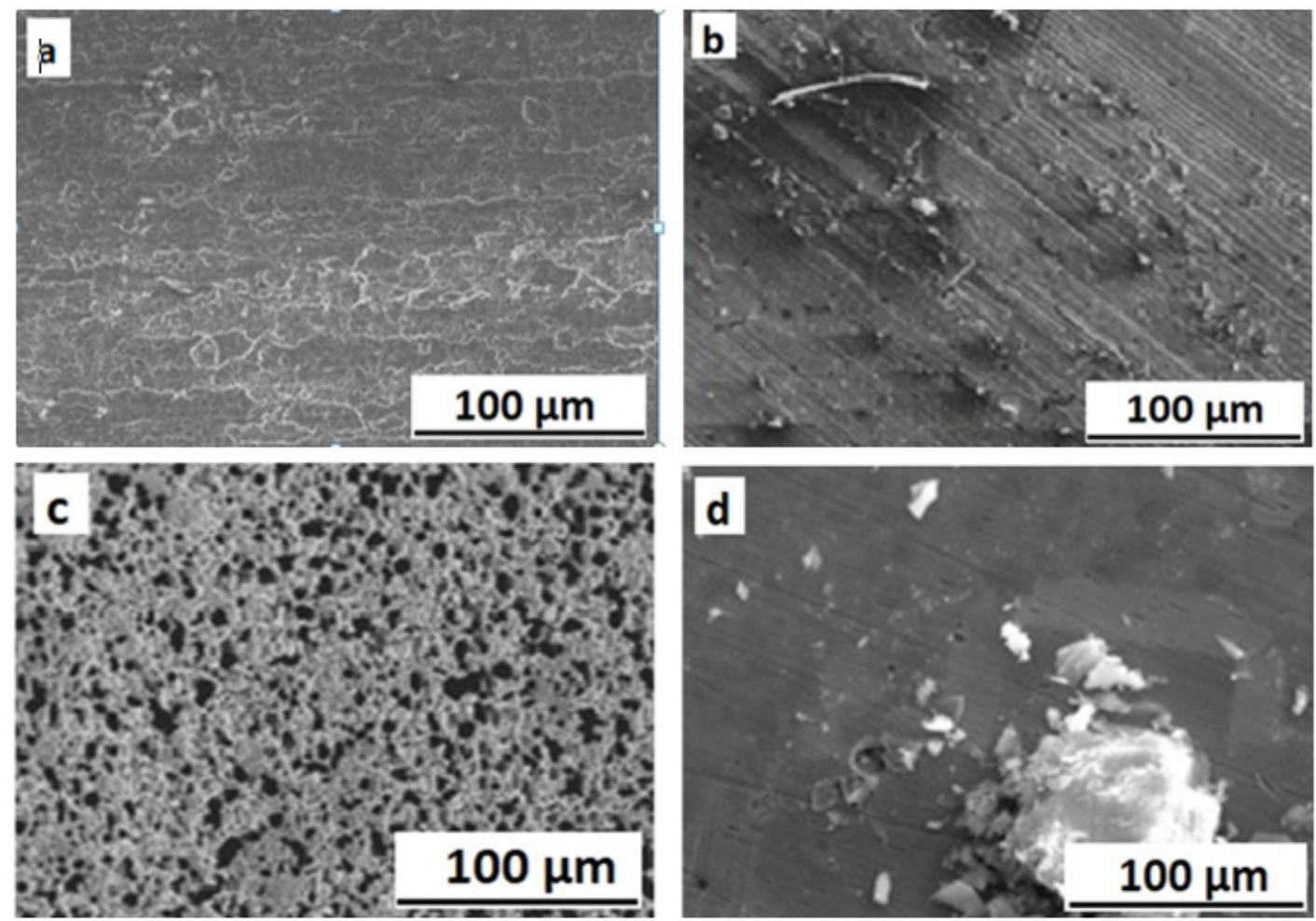

Figure 6. Surface morphology of 304 stainless steel after corrosion in (a) untreated $304 \mathrm{SS}$, (b) $3.5 \% \mathrm{NaCl}+\mathrm{CO}_{2}$ environment, (c) $3.5 \% \mathrm{NaCl}+\mathrm{CO}_{2}+\mathrm{H}_{2} \mathrm{~S}$ environment, (d) $3.5 \% \mathrm{NaCl}$ solution.

Figure $7 \mathrm{~b}$ presents the Raman spectroscopy curve of the sample corroded in $\mathrm{NaCl}$ solution saturated with $\mathrm{CO}_{2}$ and $\mathrm{H}_{2} \mathrm{~S}$. During the dissolution of $\mathrm{H}_{2} \mathrm{~S}$ in the solution, a porous and loose iron sufide layer formed due to the absorbance of $\mathrm{HS}^{-}$ion, which delayed the formation of $\mathrm{FeCO}_{3}$. As a result, the remained $\mathrm{Fe}_{3} \mathrm{C}$ was effortlessly wrinkled off in the dynamic aqueous phase. Furthermore, the FeS layer that is porous and cracked iron may contain little $\mathrm{Fe}_{3} \mathrm{C}$, and it also effortlessly spalled off due to the poor bond stress of the scale to steel matrix.

It is well known that the iron sulfides formed in $\mathrm{H}_{2} \mathrm{~S}$-saturated solutions using electrochemical techniques [41]. The Raman spectrum of the sample after corrosion is in good agreement with the spectra attributed to the iron sulfide.

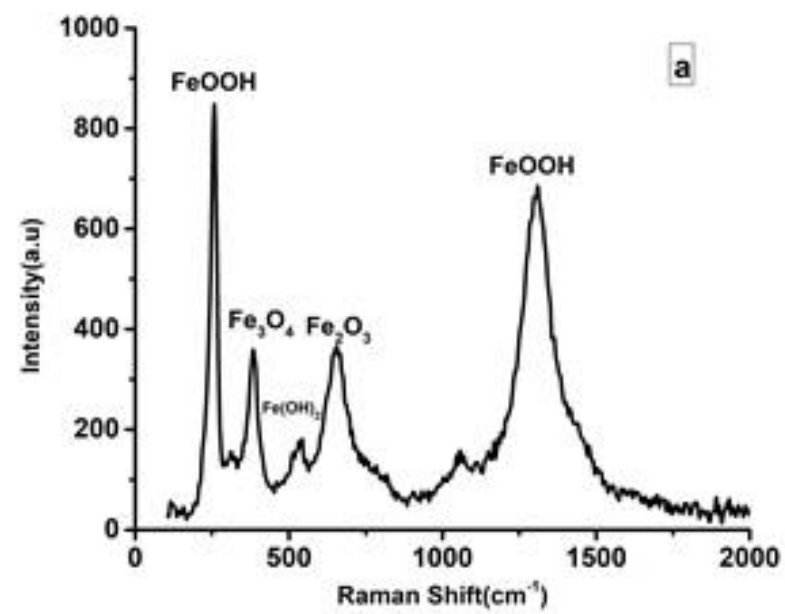

Figure 7. Cont. 

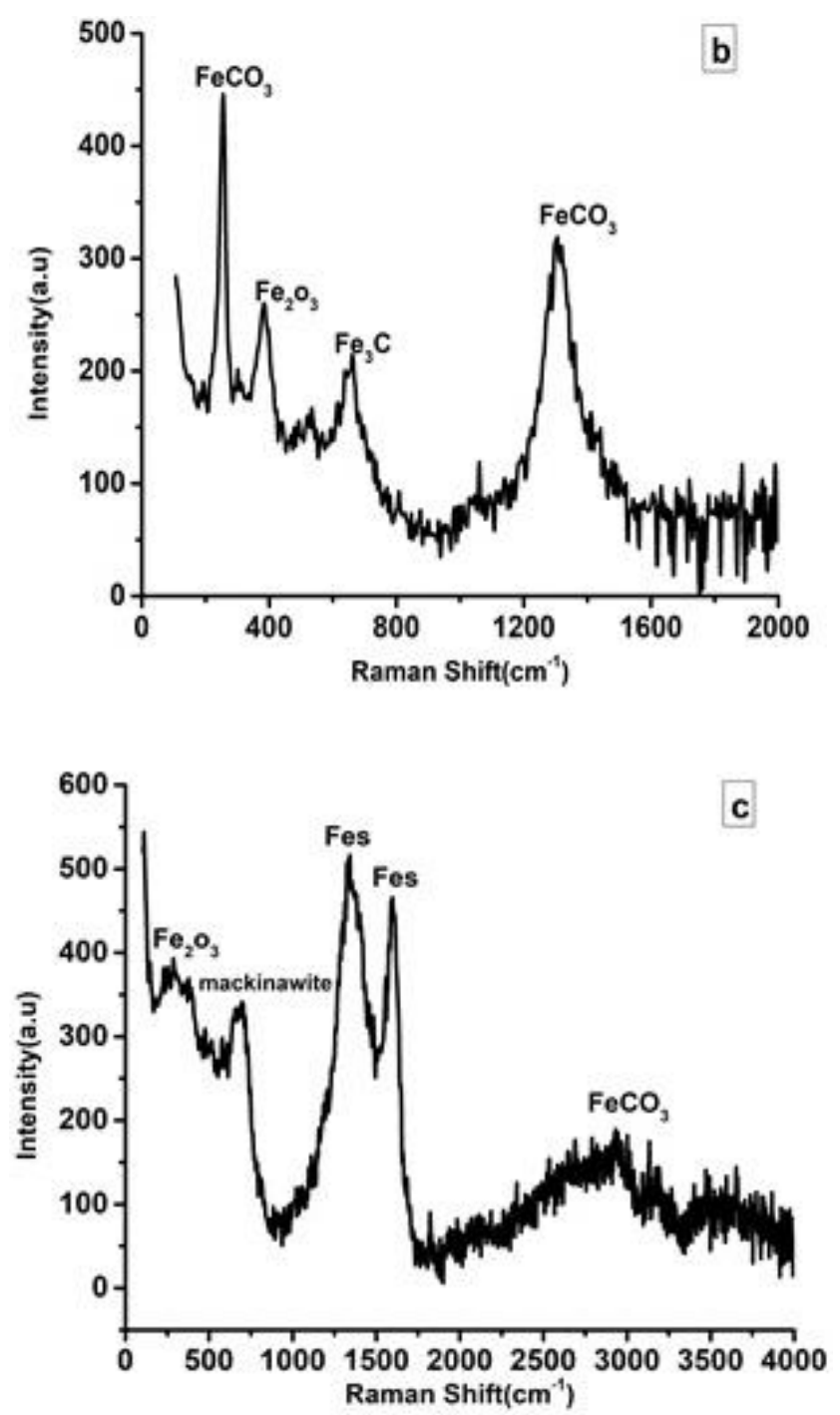

Figure 7. Raman spectroscopy after a potentiodynamic polarization test in $\mathrm{pH} 7$ for three different solutions: (a) $3.5 \% \mathrm{NaCl}$ solution, (b) $3.5 \% \mathrm{NaCl}+\mathrm{CO}_{2}$ environment, (c) $3.5 \% \mathrm{NaCl}+\mathrm{CO}_{2}+\mathrm{H}_{2} \mathrm{~S}$ environment.

\section{Conclusions}

The corrosion behavior of 304 ASS steel has been studied under simulated sea environmental conditions in the presence of $\mathrm{CO}_{2}$ and $\mathrm{H}_{2} \mathrm{~S}$. Both $\mathrm{H}_{2} \mathrm{~S}$ and $\mathrm{Cl}^{-}$ions present in sea water can decrease the corrosion resistance of the 304 SS sample. However, in a $\mathrm{CO}_{2}$-containing environment, due to the formation of stable iron carbonate, there was a positive effect on the corrosion resistance of the 304 ASS sample. The $\mathrm{pH}$ also plays an important role. The corrosion rate was in general high at lower $\mathrm{pH}$ level. So, lower $\mathrm{pH}$ and a combination of $\mathrm{CO}_{2}+\mathrm{H}_{2} \mathrm{~S}$ with $3.5 \% \mathrm{NaCl}$ has the most fatal effect on the corrosion resistance property of the 304 ASS sample. Raman spectroscopy analysis shows that the passive film formed under a saturated $\mathrm{CO}_{2}$ environment is composed of $\mathrm{FeCO}_{3}$ and is considered as the primary reason for this decreasing corrosion rate.

Author Contributions: Conceptualization, H.S.A. and A.H.S.; methodology, H.S.A.; software, H.S.A.; validation, A.H.S.; formal analysis, H.S.A.; investigation, H.S.A.; resources, H.S.A.; data curation, A.H.S.; writing-original draft preparation, H.S.A. and A.H.S.; writing-review and editing, H.S.A.; visualization, H.S.A.; supervision, H.S.A.; project administration, A.H.S.; funding acquisition, A.H.S. All authors have read and agreed to the published version of the manuscript.

Funding: This research is funded by Researchers Supporting Project number (RSP-2021/373), King Saud University, Riyadh, Saudi Arabia. 
Institutional Review Board Statement: Not applicable.

Informed Consent Statement: Not applicable.

Data Availability Statement: Not applicable.

Acknowledgments: The authors would like to acknowledge the Researchers Supporting Project number (RSP-2021/373), King Saud University, Riyadh, Saudi Arabia.

Conflicts of Interest: The authors declare no conflict of interest.

\section{References}

1. Moiseeva, L.S.; Kuksina, O.D. Predicting the Corrosion Aggressiveness of $\mathrm{CO}_{2}$-containing Media in Oil and Gas Wells. Chem. Pet. Eng. 2000, 36, 307-311. [CrossRef]

2. Nešić, S. Key Issues Related to Modelling of Internal Corrosion of Oil and Gas Pipelines-A Review. Corros. Sci. 2007, 49, 4308-4338. [CrossRef]

3. Drugli, J.M.; Rogne, T.; Svenning, M.; Axelsen, S.; Enerhaug, J. The Effect of Buffered Solutions in Corrosion Testing of Alloyed 13 $\%$ Cr Martensitic Stainless Steels for Mildly Sour Applications. In Proceedings of the NACE-International Corrosion Conference Series, San Antonio, TX, USA, April 1999; pp. 99-586.

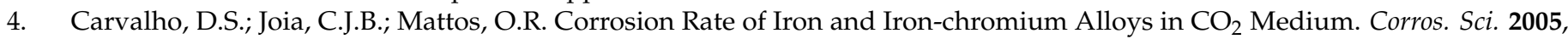
47, 2974-2986. [CrossRef]

5. Linter, B.; Burstein, G. Reactions of Pipeline Steels in Carbon Dioxide Solutions. Corros. Sci. 1999, 41, 117-139. [CrossRef]

6. Seiersten, M. Material Selection for Separation, Transportation and Disposal of $\mathrm{CO}_{2}$. In Proceedings of the NACE-International Corrosion Conference Series, Houston, TX, USA, March 2001; p. 01042.

7. Abdo, H.S.; Abdus Samad, U.; Mohammed, J.A.; Ragab, S.A.; Seikh, A.H. Mitigating Corrosion Effects of Ti-48Al-2Cr-2Nb Alloy Fabricated via Electron Beam Melting (EBM) Technique by Regulating the Immersion Conditions. Crystals 2021, 11, 889. [CrossRef]

8. Storage, G.; Dioxide, C. Carbon Dioxide Capture for Storage in Deep Geologic Formations-Results from $\mathrm{CO}_{2}$ Capture Project, Volume 1: Capture and Separation of Carbon Dioxide form Combustion; Elsevier Publishing: Amsterdam, The Netherlands, 2005.

9. Reyes, A.G.; Trompetter, W.J.; Britten, K.; Searle, J. Mineral Deposits in the Rotokawa Geothermal Pipelines, New Zealand. J. Volcanol. Geotherm. Res. 2003, 119, 215-239. [CrossRef]

10. Cui, Z.D.; Wu, S.L.; Zhu, S.L.; Yang, X.J. Study on Corrosion Properties of Pipelines in Simulated Produced Water Saturated with Supercritical $\mathrm{CO}_{2}$. Appl. Surf. Sci. 2006, 252, 2368-2374. [CrossRef]

11. López, D.; Schreiner, W.; de Sánchez, S.; Simison, S. The Influence of Carbon Steel Microstructure on Corrosion Layers. Appl. Surf. Sci. 2003, 207, 69-85. [CrossRef]

12. López, D.A.; Pérez, T.; Simison, S.N. The Influence of Microstructure and Chemical Composition of Carbon and Low Alloy Steels in $\mathrm{CO}_{2}$ Corrosion. A state-of-the-art Appraisal. Mater. Des. 2003, 24, 561-575. [CrossRef]

13. Banaś, J.; Lelek-Borkowska, U.; Mazurkiewicz, B.; Solarski, W. Effect of $\mathrm{CO}_{2}$ and $\mathrm{H}_{2} \mathrm{~S}$ on the Composition and Stability of Passive Film on Iron Alloys in Geothermal Water. Electrochim. Acta 2007, 52, 5704-5714. [CrossRef]

14. Abdo, H.S.; Seikh, A.H.; Mohammed, J.A.; Uzzaman, T. Ameliorative Corrosion Resistance and Microstructure Characterization of 2205 Duplex Stainless Steel by Regulating the Parameters of Pulsed Nd:YAG Laser Beam Welding. Metals 2021, $11,1206$. [CrossRef]

15. Inaba, H.; Kimura, M.; Yokokawa, H. An Analysis of the Corrosion Resistance of Low Chromium-steel in a Wet $\mathrm{CO}_{2}$ Environment by the Use of an Electrochemical Potential Diagram. Corros. Sci. 1996, 38, 1449-1461. [CrossRef]

16. Carew, J.; Akashah, S. Prediction Techniques for Materials Performance in the Crude Oil Production Systems. Model. Simul. Mater. Sci. Eng. 1994, 2, 371-382. [CrossRef]

17. Wu, S.L.; Cui, Z.D.; He, F.; Bai, Z.Q.; Zhu, S.L.; Yang, X.J. Characterization of the Surface Film Formed from Carbon Dioxide Corrosion on N80 Steel. Mater. Lett. 2004, 58, 1076-1081. [CrossRef]

18. Abdo, H.S.; Seikh, A.H.; Mohammed, J.A.; Soliman, M.S. Alloying Elements Effects on Electrical Conductivity and Mechanical Properties of Newly Fabricated Al Based Alloys Produced by Conventional Casting Process. Materials 2021, 14, 3971. [CrossRef]

19. Heitkemper, M.; Fischer, A.; Bohne, C.; Pyzalla, A. Verschleißverhalten Des Laserwärmebehandelten, Hochstickstofflegierten Werkzeugstahls X30CrMoN15 1. Mater. Sci. Eng. Technol. 2000, 31, 918-922. [CrossRef]

20. Abdo, H.S.; Seikh, A.H.; Mandal, B.B.; Mohammed, J.A.; Ragab, S.A.; Abdo, M.S. Microstructural Characterization and CorrosionResistance Behavior of Dual-Phase Steels Compared to Conventional Rebar. Crystals 2020, 10, 1068. [CrossRef]

21. Isfahany, A.N.; Saghafian, H.; Borhani, G. The Effect of Heat Treatment on Mechanical Properties and Corrosion Behavior of AISI420 Martensitic Stainless Steel. J. Alloys Compd. 2011, 509, 3931-3936. [CrossRef]

22. Kemp, M.; van Bennekom, A.; Robinson, F.P.A. Evaluation of the Corrosion and Mechanical Properties of a Range of Experimental Cr-Mn Stainless Steels. Mater. Sci. Eng. A 1995, 199, 183-194. [CrossRef]

23. Tahara, A.; Shinohara, T. Influence of the Alloy Element on Corrosion Morphology of the Low Alloy Steels Exposed to the Atmospheric Environments. Corros. Sci. 2005, 47, 2589-2598. [CrossRef] 
24. Brown, B.; Parakala, S.R.; Nesic, S. $\mathrm{CO}_{2}$ corrosion in the presence of trace amounts of $\mathrm{H}_{2} \mathrm{~S}$. NACE Meet. paper no. NACE-04736, 28 March-1 April 2004.

25. Moreira, R.M.; Franco, C.V.; Joia, C.J.B.M.; Giordana, S.; Mattos, O.R. The Effects of Temperature and Hydrodynamics on the $\mathrm{CO}_{2}$ Corrosion of $13 \mathrm{Cr}$ and $13 \mathrm{Cr} 5 \mathrm{Ni} 2 \mathrm{Mo}$ Stainless Steels in the Presence of Free Acetic Acid. Corros. Sci. 2004, 46, $2987-3003$. [CrossRef]

26. Abdo, H.S.; Seikh, A.H.; Mohammed, J.A.; Luqman, M.; Ragab, S.A.; Almotairy, S.M. Influence of Chloride Ions on Electrochemical Corrosion Behavior of Dual-Phase Steel over Conventional Rebar in Pore Solution. Appl. Sci. 2020, 10, 4568. [CrossRef]

27. Shoesmith, D.W. The Formation of Ferrous Monosulfide Polymorphs during the Corrosion of Iron by Aqueous Hydrogen Sulfide at $21^{\circ}$ C. J. Electrochem. Soc. 1980, 127, 1007. [CrossRef]

28. Ma, H.; Cheng, X.; Li, G.; Chen, S.; Quan, Z.; Zhao, S.; Niu, L. The Influence of Hydrogen Sulfide on Corrosion of Iron under Different Conditions. Corros. Sci. 2000, 42, 1669-1683. [CrossRef]

29. López-Rendón, R.; Alejandre, J. Molecular Dynamics Simulations of the Solubility of $\mathrm{H}_{2} \mathrm{~S}_{\text {and }} \mathrm{CO}_{2}$ in Water. J. Mex. Chem. Soc. 2008, 52, 88-92.

30. Srinivasan, S.; Kane, R.D. Prediction of Corrosivity of $\mathrm{CO}_{2} / \mathrm{H}_{2} \mathrm{~S}$ Production Environments. In Proceedings of the NACEInternational Corrosion Conference Series, Denver, CO, USA, March 1996.

31. Sun, W. Kinetics of Iron Carbonate and Iron Sulfide Scale Formation in $\mathrm{CO}_{2} / \mathrm{H}_{2} \mathrm{~S}$ Corrosion. Ph.D. Thesis, Ohio University, Athens, OH, USA, 2006.

32. Donik, Č.; Paulin, I.; Jenko, M. Influence of MnS Inclusions on the Corrosion of Austenitic Stainless Steels. Mater. Tehnol. 2010, $44,67-72$.

33. Ikeda, A.; Mukai, S.; Ueda, M. Corrosion Behavior of 9 to 25\% Cr Steels in Wet CO 2 Environments. Corrosion 1985, 41, 185-192. [CrossRef]

34. Shukla, A.K.; Balasubramaniam, R.; Bhargava, S. Properties of Passive Film Formed on CP Titanium, Ti-6Al-4V and Ti-13.4Al-29Nb Alloys in Simulated Human Body Conditions. Intermetallics 2005, 13, 631-637. [CrossRef]

35. Kobayashi, E.; Wang, T.J.; Doi, H.; Yoneyama, T.; Hamanaka, H. Mechanical Properties and Corrosion Resistance of Ti-6Al-7Nb Alloy Dental Castings. J. Mater. Sci. Mater. Med. 1998, 9, 567. [CrossRef]

36. Sánchez, M.; Gregori, J.; Alonso, C.; García-Jareño, J.J.; Takenouti, H.; Vicente, F. Electrochemical Impedance Spectroscopy for Studying Passive Layers on Steel Rebars Immersed in Alkaline Solutions Simulating Concrete pores. Electrochim. Acta 2007, 52, 7634-7641. [CrossRef]

37. Thibeau, R.J.; Brown, C.W.; Heidersbach, R.H. Raman Spectra of Possible Corrosion Products of Iron. Appl. Spectrosc. 1978, 32, 532-535. [CrossRef]

38. Farrow, R.L.; Mattern, P.L.; Nagelberg, A.S. Characterization of Surface Oxides by Raman Spectroscopy. Appl. Phys. Lett. 1980, 36, 212-214. [CrossRef]

39. Zhang, G.A.; Zeng, Y.; Guo, X.P.; Jiang, F.; Shi, D.Y.; Chen, Z.Y. Electrochemical Corrosion Behavior of Carbon Steel under Dynamic High Pressure $\mathrm{H}_{2} \mathrm{~S} / \mathrm{CO}_{2}$ Environment. Corros. Sci. 2012, 65, 37-47. [CrossRef]

40. Gao, M.; Pang, X.; Gao, K. The Growth Mechanism of $\mathrm{CO}_{2}$ Corrosion Product Films. Corros. Sci. 2011, 53, 557-568. [CrossRef]

41. Choi, Y.S.; Hassani, S.; Vu, T.N.; Nesic, S.; Abas, A.Z.B. Effect of $\mathrm{H}_{2} \mathrm{~S}$ on the Corrosion Behavior of Pipeline Steels in Supercritical and Liquid $\mathrm{CO}_{2}$ Environments. Corrosion 2016, 72, 999-1009. [CrossRef] 